\title{
Typology of metaphors with the gustatory target domain in Polish wine discourse
}

\begin{abstract}
Although wine culture is quite a new phenomenon in Poland, Polish wine blogs on the Internet are numerous, and a specific wine language is rapidly emerging. The Polish lexical field of taste is rather poor compared to other perceptual fields. It is obvious that the limited lexical repertoire does not suffice to describe such a multidimensional experience as wine tasting. Polish wine discourse is permeated with various kinds of metaphors, starting from basic terms like ciało wina 'the body of a wine,' through more creative, but still lexicalised metaphors, e.g. leciutka nuta korkowa 'a light note of the cork,' to intricate, elaborated, semi-narrative metaphors, e.g. Tyle innych burgundów $z$ lat 90-tych cierpi na sklerozę i haluksy 'So many other burgundies from the 1990s suffer from sclerosis and bunions.' A number of metaphoric wine terms have of course been borrowed from French or English, but there are also many new metaphors, specific for the Polish language and culture. The material for the analysis consists of blog excerpts taken from "Synamet"-a corpus of synesthetic metaphors in Polish. The paper aims at examining taste metaphors that are used in Polish wine blogs and proposing a preliminary typology of metaphors recurring in wine discourse.
\end{abstract}

Key words: metaphor, synesthesia, wine discourse.

\section{Introduction}

Recently, a considerable literature has grown around the theme of winespeak. Researchers have noticed that wine discourse is a valuable source of a variety of metaphors. Starting from the pioneering work by Adrienne Lehrer (1975) Talking about Wine (followed by a monograph, see Lehrer 2009 [1983]), the figurative language of wine reviewers has been analyzed in many languages, i.a. in French (Amoraritei 2002, Negro 2012), English (Caballero 1996, 2007; Caballero and SuárezToste 2010; Paradis 2010), Australian English (Creed 2014), and Italian (Țenescu 2014). A major account of the language of wine reviews was provided by Carita Paradis and Mats Eeg-Olofsson (2013), who advocate lexical syncretism of wine descriptors, and argue that "synesthetically flexible notions map onto the same primitive concepts for the different sensory perceptions" (Paradis and Eeg-Olofsson 2013: 38). The role of personification schemata in English winespeak was studied by Ernesto Suárez-Toste (2007). Although quite a lot of research has been carried out on wine 
metaphors in English up till now, too little attention has been paid to Polish wine discourse. Apart from Zawisławska (2015), there is a general lack of analysis of metaphors in Polish wine reviews. The purpose of this paper is to present a classification of wine metaphors in Polish blogs, and to examine creative and elaborated metaphors (in contrast to lexicalised wine terminology) that require a much more complex analysis. Data for this study were collected using excerpts from blogs about wine collected in Synamet-the Microcorpus of Synesthetic Metaphors in Polish, which aims at creating a semantically and grammatically annotated corpus of Polish synesthetic metaphors. The corpus contains texts excerpted from blogs devoted to perfume, wine, beer, cigars, Yerba Mate, tea or coffee, as well as culinary blogs, music blogs, art blogs, and massage and wellness blogs. The wide selection of texts in the corpus allows us to study the ways the particular senses (taste, smell, sight, hearing, touch) and complex perceptual experiences are described. At the present moment, Synamet comprises 6158 annotated metaphorical units.

The methodological approach adopted in this study draws on both the methodology based on frame semantics (Fillmore 1982) and conceptual metaphor theory (CMT) by Lakoff and Johnson (1980). Instead of the term "domain" we use "frame" because while the internal structure of domains is not fully clear, frames are described as ordered structures within which there are categories "slots" and their values "fillers". Frames are hierarchically organized, and they may represent various events, states, objects, and situations. Along these lines, the metaphorization process may be described as "frame shifting". Coulson defines this phenomenon as a "semantic reanalysis process that reorganizes existing information into a new frame" (2001: 34). It follows that some elements of a frame evoking specific sensations (e.g. taste) as its topic may become regrouped under the influence of a vehicle activating a frame of some other sensory perception (e.g. vision).

Since there are some interesting and distinctive features of Polish metaphors, our research can give new insight into the problem of metaphor with the gustatory target domain.

\section{Lexical field of taste in Polish and wine tasting}

Taste is the oldest and the most universal sense in the whole population of vertebrates (Mitrenga 2009: 26). The sensation is produced when a substance in the mouth reacts chemically with taste receptor cells located on the taste buds. The gustatory perception is in fact a mixture of several sensations: not only taste, but also temperature, texture, and smell. The taste sensation is analyzed in the gustatory area located in the cortex of the brain, but also in the limbic system, which is responsible for emotions. Therefore, the taste sensation is very subjective and may evoke certain feelings and memories, as is probably best shown in the famous quote from Proust's novel:

No sooner had the warm liquid mixed with the crumbs touched my palate than a shudder ran through me and I stopped, intent upon the extraordinary thing that was happening to me. An exquisite pleasure had invaded my senses, something isolated, detached, with no suggestion of its origin. And at once the vicissitudes of life had become indifferent to me, its disasters innocuous, its brevity illusory - this new sensation having had on me the effect which love has of filling me with a precious essence; or rather this 
essence was not in me it was me.... Whence did it come? What did it mean? How could I seize and apprehend it? ... And suddenly the memory revealed itself. The taste was that of the little piece of madeleine which on Sunday mornings at Combray (because on those mornings I did not go out before mass), when I went to say good morning to her in her bedroom, my aunt Léonie used to give me, dipping it first in her own cup of tea or tisane. The sight of the little madeleine had recalled nothing to my mind before I tasted it. (Marcel Proust, In Search of Lost Time, transl. by C.K. Scott Moncrieff and Terence Kilmartin)

The basic tastes that a human can feel are:

1. salty (the standard substance - table salt);

2. sour (the standard substance - tartaric acid or citric acid);

3. sweet (the standard substance - saccharin);

4. bitter (the standard substance - caffeine, quinine).

Two more tastes are sometimes distinguished: the umami taste (described as the taste of meat: the standard substance - monosodium glutamate); and the fatty taste (the standard substance fatty acids).

The gustatory perception is a dynamic one. Our taste buds react with different speeds to various tastes. The fastest reaction is evoked by the salty taste, then sweet, sour, and the slowest reaction is to the bitter taste (Skolik 2011: 21-24).

The lexical field of taste in Polish (likewise in other Indo-European languages) is much more restricted than fields of visual or auditory perception. It encompasses a narrow group of verbs that denote: 1) tasting, e.g. kosztować 'to taste', posmakować 'to sample', degustować 'to savor'; 2) the subject's approval or disapproval of a particular taste sensation, e.g. smakować [jakoś] 'to have a particular flavour', zasmakować 'to develop a taste for something', posmakować ' to find sth delicious'; 3) a change of taste, e.g. jetczeć 'to go rancid', kisić sie 'to marinate', gorzknieć 'to turn bitter'. Most nouns from the analyzed lexical field are names of a specific taste, e.g. gorycz 'bitterness', słodycz 'sweetness', kwaśność 'acidity'. Apart from that, the taste field contains nouns referring in general to: 1) neutral gustatory sensation: smak 'taste', posmak 'aftertaste' or 2) negative gustatory sensation: absmak 'distaste', niesmak 'bad taste'. There are also nouns denoting the high tastiness of the object of perception, e.g. pyszności 'delicious things', przysmak 'delicacy', rarytas 'rarity' or a specific taste of an object of perception, e.g. słodycze 'sweets', łakocie 'sweet things', kwasek 'citric acid'.

Wine tasting is a relatively new phenomenon in Poland. For a very long time the typical alcohols drunk by the Polish people have been vodka and beer. In 2016 wine consumption in Poland amounted to 5.5 liters per capita (in 2013 it was only 3 liters per capita). Still, Poland is far behind other European countries-in the Czech Republic people drink 21 liters per capita, in Germany-28, in Italy-44, and a typical French person drinks 50 liters of wine yearly. Although the Polish do not drink as much wine as their Western neighbors, Poland is now the fastest growing wine market in Europe (Naszkowska 2017). The progress in the wine market is followed by a rapid development of wine blogs and a specific winespeak. Due to the very poor lexical field of taste 
in Polish, it is not surprising that wine reviewers must use figurative language to describe such a complex and dynamic act as wine tasting.

\section{Frame of wine tasting and metaphorical terms classification}

Wine develops in a long and complicated process of fermentation. As a result, we get an alcohol that consists of water, sugar, acids, tannins, ethanol, and glycerol. Various combinations of these elements can produce different taste impressions. Wine tasting is a multi-faceted act, integrating several senses:

1. visual sensation - a wine taster evaluates the color and shades of wine,

2. olfactory sensation-a wine taster detects the aromas of wine,

3. gustatory and tactile sensations (e.g. getting numb by acids) - a wine taster feels the taste of wine.

The frame of wine tasting consists of the following elements:

1. the dominant taste of wine (sweet, acid, bitter),

2. intensity of wine taste,

3. detectability of alcohol in wine,

4. water and alcohol/extract balance in wine,

5. balance of tastes in wine,

6. durability of aftertaste.

All the elements of the frame are described by terms of metaphorical provenance, see Table 1.

Table 1. Frame of wine tasting.

\section{FRAME ELEMENT}

DOMINANT TASTE

the dominant taste of wine is bitter (but not unduly)

the dominant taste of wine is unduly bitter

the dominant taste of wine is acid (but not unduly)

the dominant taste of wine is unduly acid

the dominant taste of wine is sweet

the dominant taste of wine is unduly sweet ${ }^{12}$

\section{METAPHOR}

wino jest jędrne 'wine is firm'
wino jest sprężyste 'wine is pliant'
wino jest solidne 'wine is robust'
wino jest twarde 'wine is hard'
wino jest sztywne 'wine is rigid'
wino jest rześkie 'wine is fresh'
wino jest rozłożyste 'wine is spreading'
wino jest zielone 'wine is green'
wino jest agresywne 'wine is aggressive'
wino jest łagodne 'wine is gentle'
wino jest miękkie 'wine is soft'
wino jest wiotkie 'wine is frail'
wino z wigorem 'bouncy wine'

wino jest jędrne 'wine is firm' wino jest sprężyste 'wine is pliant' wino jest solidne 'wine is robust' wino jest twarde 'wine is hard' iest sztywne "wine is rigid"

wino jest rześkie 'wine is fresh' wino jest rozłożyste 'wine is spreading'

wino jest zielone 'wine is green' wino jest łagodne 'wine is gentle' wino jest miękkie 'wine is soft' wino $z$ wigorem 'bouncy wine'

1 Although in general Polish usage the words wiotki and wigor do not have a pejorative meaning, in winespeak they tend to signal a negative evaluation of the product. 


\section{INTENSITY OF TASTE \\ high intensity of wine taste}

low intensity of wine taste

\section{ALCOHOL DETECTABILITY}

alcohol is incisive

alcohol is not incisive

alcohol is too strong

WATER AND ALCOHOL/EXTRACT BALANCE

alcohol/extract is incisive

alcohol/extract is not incisive

\section{TASTES BALANCE}

tastes are well balanced

tastes are not balanced

DURABILITY OF AFTERTASTE

aftertaste lasts for a short time

aftertaste lasts for a long time wino jest bogate 'wine is rich' wino jest głębokie 'wine is deep'

wino jest nudne 'wine is boring' wino jest skąpe 'wine is mingy' wino jest proste 'wine is simple' wino jest płytkie 'wine is shallow' wino jest nieme 'wine is dumb'

wino jest gorące 'wine is hot' wino jest chłodne 'wine is cold' wino jest palące 'wine is torrid' wino jest ogniste 'wine is fiery'

wino ma pełne ciało 'wine is full-bodied' wino jest mięsiste 'wine is chunky' wino jest solidne 'wine is solid' wino jest masywne 'wine is bulky' wino jest dobrze zbudowane 'wine is hunky' wino jest krągłe 'wine is round' wino jest mocne 'wine is strong' wino jest ciężkie 'wine is heavy' wino jest męskie 'wine is manly' wino jest cienkie 'wine is thin' wino jest lekkie 'wine is light' wino jest kobiece 'wine is feminine'

wino jest zrównoważone 'wine is well balanced' wino ma charakter 'wine has character' wino jest eleganckie 'wine is elegant' wino jest aksamitne 'wine is velvety' wino jest rasowe 'wine is pure-bred' wino jest bez wyrazu 'wine is featureless'

wino jest krótkie 'wine is short' wino jest długie 'wine is long'

The wine terms are based on the following metaphorical schemata:

1. WINE IS A PHYSICAL SOLID OBJECT

1.1. IT IS A FLEXIBLE/NON-FLEXIBLE PHYSICAL OBJECT (wine is pliant/rigid)

1.2. IT HAS SHAPE (wine is round)

1.3. IT HAS LENGTH (wine is short)

1.4. IT HAS WIDTH (wine is thin)

1.5. IT HAS DEPTH (A CONTAINER) (wine is deep)

1.6. IT HAS TEMPERATURE (wine is hot/cold) 
1.7. IT HAS WEIGHT (wine is light)

1.8. IT HAS A SURFACE WITH A SPECIFIC TEXTURE (FABRIC) (wine is velvety)

2. WINE IS AN ANIMATE BEING

2.1. WINE IS A PLANT (wine is green)

2.2. WINE IS AN ANIMAL (wine is pure-bred)

2.3. WINE IS A HUMAN

2.3.1. WINE HAS A BODY ${ }^{2}$ (wine is full-bodied)

2.3.2. WINE HAS A PERSONALITY (wine is gentle)

2.3.3. WINE HAS GENDER (manly/feminine wine)

2.3.4. WINE CAN SPEAK (wine is dumb)

2.3.5. WINE WEARS CLOTHES (wine is elegant)

2.3.6. WINE CAN HAVE A FORTUNE (wine is rich)

In general, most metaphorical terms used in Polish winespeak present wine as a three-dimensional object or a person with certain physical and psychological features. Such visualization underlines the complexity of sensory perception during wine tasting. Some terms undoubtedly have metonymic origins. Since alcohol literally imparts a burning sensation to our tongue, it comes as no surprise that alcohol predominance in wine is described by the activation of the fire frame (hot, fiery). Similarly, the metaphors indicating that wine is rich in extract and activating the robustness or weight frames as their source can be explained by the fact that alcohols and sugars have a much higher viscosity than water, and as a result may be perceived as heavier, thicker in our mouth.

The most typical feature of winespeak is the concomitance of several metaphorical schemata in one sentence (so-called "mixed metaphors" ${ }^{3}$ ). For example, wine can be described simultaneously as velvety, warm, light and long. Sometimes in one text two different schemata are mixed: WINE IS A Physical object and Wine is An ANimate Being, E.G. (1):

(1)

\begin{tabular}{|l|l|l|l|l|l|}
\hline Santo Stefano & $i$ & Santo Stefano Riserva & to & wina & głębokie, \\
\hline Santo Stefano.PR & and & Santo Stefano Riserva.PR & be.COP & wine.NOM.PL & deep \\
\hline długie, & eleganckie, & 0 & twardej & ramie & garbników \\
\hline
\end{tabular}

\footnotetext{
2 We are aware that animals also have bodies, but language is highly anthropocentric. Moreover, creative metaphors used in Polish winespeak (see examples (6)-(8)) clearly suggest that it is the human body that speakers had in mind.

3 The term "mixed metaphors" is used extensively in English stylistics and rhetoric. The occurrence of mixed metaphors in texts has traditionally been seen as a sign of the author's lack of stylistic competence, and the critique of such practice was voiced for instance in Henry B. Lathrop's manual: "Sometimes writers go so far as to forget the metaphorical significance of their words as to combine distinctly incongruous metaphors, producing what are called mixed metaphors" (Lathrop 1920: 200, cited in Gibbs 2016: vii). However, recent studies point to the fact that mixing metaphors is actually common and natural in various discourse types.
} 


\begin{tabular}{|l|l|l|l|l|l|}
\hline long & elegant & with & hard & frame.LOC & tannin.GEN.PL \\
\hline azarazem & mięsistej, & sutej & materii. & \\
\hline simultaneously & fleshy & ample & fabric.LOC & \\
\hline
\end{tabular}

'Santo Stefano and Santo Stefano Riserva are deep wines, long, elegant with a sturdy tannin frame and fleshy, ample fabric.'

Mixing various perceptual and non-perceptual source frames in metaphors is a typical feature of wine blogs. Paradis and Hommerberg believe that:

...the elusive mixture of sensations in wine tasting takes the form of mixed metonymizations, metaphors and similes in wine reviewing discourse. Such construals of meaning are taken to be motivated by the fact that concrete word meanings elicit qualitatively different processing in the form of mental imagery than abstract word meaning in that they evoke rich sensory experiences which are intimately tied up with our experience in life (Paradis and Hommerberg 2016: 181).

\section{Elaborated metaphors in Polish wine blogs}

Most terms used in Polish wine discourse are of course borrowings. Nevertheless, Polish wine blogs are remarkably rich in new, creative metaphors that expand the basic metaphorical schemata. In example (2), wine is pictured as a carving in almond wood. The metaphor, based on the schema WINE IS A PHYSICAL OBJECT, brings out the three-dimensionality of wine taste and its almond aroma.

(2)

\begin{tabular}{|c|c|c|c|c|c|c|}
\hline Znakomite & \multicolumn{2}{|l|}{ wino, } & \multicolumn{2}{|l|}{ sprawiające } & wrażenie & wyrzeźbionego \\
\hline exquisite & \multicolumn{2}{|l|}{ wine.NOM } & \multicolumn{2}{|l|}{ make.PART } & impression.ACC & carve.PERF \\
\hline$w$ & migdałowym & drewnie & (to & pewnie & nuta & z aromatu). \\
\hline in & almond & wood.LOC & it & surely & note.NOM & out of aroma \\
\hline
\end{tabular}

'An exquisite wine, as if carved in almond wood (it must be a note of the aroma).'

In example (3), the speaker elaborates on a quite conventional metaphor WINE IS FABRIC. A typical description of fabric features (e.g. adjectives dense, gauzy) is in fact projected onto the description of wine.

(3)

\begin{tabular}{|c|c|c|c|c|c|}
\hline Materia & wina & jest & zbita, & gęsta, & \\
\hline fabric.NOM & wine.GEN & be.PRES.SG & matted & dense & \\
\hline ale & zwiewna & jak & $w$ & perskim & dywanie - \\
\hline
\end{tabular}




\begin{tabular}{|l|l|l|l|l|l|}
\hline but & gauzy & as & in & Persian & carpet.LOC \\
\hline cieniutkim, & lecz & niezliczonej & ilości & supełków. \\
\hline thin.DIM & but & with & countless & number.LOC & knot.GEN.PL.DIM \\
\hline$W$ & Ovello & tych & supetków & zdajesię & być \\
\hline In & Ovello.PR & this.DEM.PL.MASC & knot.GEN.PL.DIM & seem.PRES & be.INF \\
\hline jeszcze & więcej & $i$ & sq & jeszcze & drobniejsze. \\
\hline even & more & and & be.PRES.PL & even & fine.PL \\
\hline Taniny & sq & mikroskopijne, & wyrafinowane, & tekstura & tego \\
\hline tannin.NOM.PL & be.PRES.PL & microscopic & sophisticated & texture.NOM & this.DEM.SG.NEUT \\
\hline wina & jest & bardzo & szlachetna. & & \\
\hline wine.GEN & be.PRES & very & noble & & \\
\hline
\end{tabular}

'The fabric of the wine is matted, dense, yet gauzy as in a Persian carpet - ultrafine but with countless knots. There seems to be even more of the knots in Ovello, and they are even finer. Tannins are microscopic, sophisticated, the texture of this wine is very noble.'

Even personifications, quite frequent in winespeak, can be more creative and elaborated. In example (4), two different wines are characterized as if they were inhabitants of the regions where they were made. Human features, pertaining both to the appearance (e.g. shaven) and behavior (e.g. unmannerly), are mapped onto the taste of the two wines.

(4)

\begin{tabular}{|l|l|l|l|l|}
\hline$I$ & choć & lubiłam & myśleć & \\
\hline and & despite & like.15T.PERS.PAST.FEM & think.INF & about \\
\hline nero & jak & o & szorstkim, & nieokrzesanym \\
\hline nero.PR & as & about & brusque & unmannerly \\
\hline Sycylijczyku & (ze & wszystkimi & tego(sic) & wadami), \\
\hline Sicilian-LOC & (with & all.PRON & this.DEM.SG & fault.INSTR.PL \\
\hline to & ogolony & $i$ & wygładzony & nero \\
\hline CONJ & shave.PART.PAS & and & smoothaway.PART.PAS & nero.PR \\
\hline od & Gigliotto & przypadłmido gustu. & & \\
\hline from & Gigliotto.PR & take to.PAST & & \\
\hline
\end{tabular}

'And even though I liked to think about Nero as of a brusque, unmannerly Sicilian (with all his flaws), I found the shaven and smoothened Gigliotto's Nero quite to my liking.'

Example (5) shows a wine as a very aggressive attacker who yells, destroys and murders dishes, whereas the specific components of taste (alcohol, fruit) are depicted as weapons. 
(5)

\begin{tabular}{|l|l|l|l|l|}
\hline Żadne & $z$ & podanych & win & nie nadawało się \\
\hline none.PRON.NEG & out of & serve.PART.PAS & wine.GEN.PL & suit.PAST.NEG \\
\hline$j$ jednak & do & jedzenia & Zakrzykiwały & każdq \\
\hline however.PART & to & food.GEN & shout.PAST.ITER & every.PRON \\
\hline potrawę- & zalewały & jq & oleista & materiq, \\
\hline dish.ACC & flood.PAST.ITER & it.PRON.SG.FEM & oily & fabric.INSTR \\
\hline niszczyły & rozbuchanym & alkoholem, & mordowały & zbyt \\
\hline destroy.PAST.ITER & lush & alcohol.INSTR & murder.PAST.ITER & too \\
\hline słodkim & owocem, & $i$ & nic & tu \\
\hline sweet & fruit.INSTR & and & nothing.PRON & here.DEM \\
\hline niepomogło & nachalne & dokwaszenie. & & \\
\hline help.PAST.NEG & aggressive & acidize.GER.PERF & & \\
\hline
\end{tabular}

'None of the wines that were served matched the food, though. They shouted down every dish, flooding it with their oily fabric, destroyed it with their lush alcohol, murdered it with fruit that was too sweet, and the aggressive acidizing was of no use at all.'

The specialist term "body of wine", which functions as a conventional wine tasting descriptor, is creatively expanded in examples (6)-(9).

In example (6), the reader's attention is focused on a specific body part, i.e. the legs. Legs normally enable a standing person to maintain balance, and the basic experience is mapped onto the domain of gustatory perception in order to communicate the complexity of impressions a wine taster gets, which evolve over time as the wine is exposed to oxygen.

(6)

\begin{tabular}{|c|c|c|c|c|}
\hline Miałem & wrażenie & jakby & wino & lekko \\
\hline have.PAST. $1^{\text {st }}$ SG.MASC & impression.ACC & as if & wine.NOM & gently \\
\hline chwiało się & na & nogach, & chociaż & im \\
\hline shake.PAST. $3^{\text {rd. SG }}$ & on & foot.LOC.PL & though & the more \\
\hline dłużej & oddychało & $w$ & karafce, & tym \\
\hline long & breathe.PAST. $3^{\text {rd. SG }}$ & in & decanter.LOC & the more \\
\hline pewniej & łapało & pion. & & \\
\hline confidently & keep.PAST.3 $3^{\text {rd. }}$ SG & upright. & & \\
\hline
\end{tabular}

'I got the impression that the wine was a bit shaky on its feet, though the longer it breathed in the decanter, the firmer it stood.' 
The anthropocentrism of language manifests itself in comparing the body of wine to that of celebrities (see example (7) alluding to Sylvester Stallone as a culturally entrenched hallmark of athleticism, and example (8) with Scarlett Johansson perceived as a paragon of a sexually attractive, curvy woman; in both cases the wine is evidently positively evaluated by the taster), or that of a muscleman on steroids (see example (9))-an image that conveys a negative evaluation.

(7)

\begin{tabular}{l|l|l|l|l|l|}
\hline Napakowane & owocem, & muskularne & niczym & Sylvester Stallone & wina. \\
\hline pack.PART.PERF & fruit.INST.SG & muscular & like & Sylvester Stallone.PR & wine.GEN.SG \\
\hline
\end{tabular}

'Crammed with fruit, muscular like a Sylvester Stallone of wine.'

(8)

\begin{tabular}{|c|c|c|c|c|}
\hline Znakomite & wino & jednocześnie & prezentujące & okrągłości, \\
\hline exquisite & wine.NOM & simultaneously & present.PART & curve.ACC.PL \\
\hline których & nie powstydziłaby się & Scarlett Johansson. & & \\
\hline which.PRON.REL & be ashamed.COND.NEG & Scarlett Johansson.PR & & \\
\hline
\end{tabular}

'An exquisite wine, at the same time revealing curves that Scarlett Johansson would not be ashamed of.'

(9)

\begin{tabular}{|l|l|l|l|l|}
\hline Dosyć & gęste, & ciężkie & wino. & Aromat \\
\hline quite.PART & thick & heavy & wine.NOM & aroma.NOM \\
\hline intensywny, & owocowy, & nadłuższqmetę & męczqcy, & ale \\
\hline intensive & fruit.ATTR & in the long run & tiresome & but \\
\hline Kto & będzie wwąchiwałsię & & $w$ & kieliszek \\
\hline who.PRON & sniff.FUT.3rd.SG.REFL & & in & glass.ACC \\
\hline przy & kotlecie? & Ciało & osiłka & na \\
\hline over & chop.LOC & body.NOM & muscleman.GEN & on \\
\hline sterydach: & niby & duży, & niby & silny, \\
\hline steroid.LOC.PL & seemingly & big & seemingly & strong \\
\hline ale & $i$ & groteskowy. & & \\
\hline but & as well & grotesque & & \\
\hline
\end{tabular}


'A quite thick, heavy wine. An intensive fruity aroma, tiresome in the long run, but who will want to sniff so diligently over a chop of meat? A body of a muscleman on steroids: he seems to be big and strong, but grotesque as well.'

The lexicalized metaphorical term "nieme wino" 'dumb wine' is developed in examples (10) and (11). Dumb wine is a negative characteristic of wine which is tasteless and devoid of aroma. However, in the following two examples the speakers make use of the concept to describe the good taste and aroma of wines. This is done by offering an image of (personified) tannins whispering in the case of a young wine that has not developed its full voice yet (see (10)), or a seemingly tacit wine that turns out to resemble a song sung in an archaic white voice technique as in example (11).

\begin{tabular}{|c|c|c|c|c|}
\hline $\begin{array}{l}\text { Mas de Daumas } \\
\text { Gassac Rouge } 2009\end{array}$ & zapowiada się & bodaj & wspanialej & od \\
\hline $\begin{array}{l}\text { Mas de Daumas } \\
\text { Gassac Rouge 2009.PR }\end{array}$ & promise.PRES.3 ${ }^{\text {rd. }}$ SG & perhaps.PART & excellent & than.COMP \\
\hline wersji & białej. & Na razie & to & jeszcze \\
\hline version.GEN & white & for the time being & be.COP & still.PART \\
\hline osesek: & gdy & go & degustowałem & $w$ \\
\hline nursling.NOM & when & it.PRON.MASC.SG & taste.PAST.1 $1^{\text {st.SG.MASC }}$ & in \\
\hline marcu, & dopiero & trafit & do & beczek. \\
\hline March.LOC & just.PART & land.PAST. ${ }^{\text {rd }}$.SG.MASC & into & barrel.GEN.PL \\
\hline Już & jednak & czuje się & świetną & równowage \\
\hline already & however.PART & feel.PRES.IMPRS & excellent & balance.ACC \\
\hline I & przede wszystkim & arcypięknq & urodę & garbników, \\
\hline and & aboveall.PART & beautiful & beauty.ACC & tannin.GEN.PL \\
\hline przemawiających & zmysłowym, & lirycznym & szeptem. & \\
\hline speak.PART & sensuous & lyrical & whisper.INSTR & \\
\hline
\end{tabular}

'Mas de Daumas Gassac Rouge 2009 seems to be even more promising than the white version. For the time being, it is still a nursling: when I tasted it in March, it had just landed in barrels. 
However, one can already feel its excellent balance and above all the superior beauty of the tannins that speak in a sensuous lyrical whisper.'

\begin{tabular}{|c|c|c|c|c|}
\hline Przez & pierwsze & dziesięć & minut & Pommier Pinot Noir 2011 \\
\hline for & first.PL & ten.NUM & minute.GEN.PL & $\begin{array}{l}\text { Pommier Pinot Noir } \\
\text { 2011.PR }\end{array}$ \\
\hline nie pachniało & zupełnie & niczym, & $w$ & ustach \\
\hline smell.PAST. ${ }^{\text {rd. SG.NEUT }}$ & completely & nothing.PRON & in & mouth.LOC \\
\hline też & zdawało się & milczeć. & Potem & powoli \\
\hline also.PART & seem.PAST. ${ }^{\text {rd }}$.SG.NEUT & be silent.INF & then & slowly \\
\hline dawało & się & odkrywać & po & kawałeczku- \\
\hline let.PAST. $3^{\text {rd }}$.SG.NEUT & itself.PRON.REFL & discover.INF & by & bit.LOC.DIM \\
\hline lilie, & odrobina & wiśni, & kwasowość, & zieloność, \\
\hline lily.NOM.PL & bit.NOM & cherry.GEN & acidity.NOM & greenness.NOM \\
\hline zero & garbnika. & Wszystko & drobne, & proste, \\
\hline zero.NUM & tannin.GEN.SG & all.PRON & small & simple \\
\hline smukłe, & czyste, & skromne, & ale & niesamowicie \\
\hline slender & pure & modest & but & incredibly \\
\hline autentyczne. & Jak & pieśń & śpiewana & białym głosem. \\
\hline authentic & like & song.NOM & sing.PART.PAS & white voice.INSTR \\
\hline Niespieszne, & nierozgadane, & mało & alkoholowe, & zupełnie \\
\hline unhurried & unchatty & little & alcohol.ATTR & completely \\
\hline \multicolumn{5}{|l|}{ niedzisiejsze. } \\
\hline old-fashioned & & & & \\
\hline
\end{tabular}


'For the first ten minutes, Pommier Pinot Noir 2011 had no smell whatsoever, it seemed to stay tacit in the mouth, too. Later on, it began to reveal itself bit by bit-lilies, a bit of cherry, acidity, greenness, no tannin. Everything was small, simple, slender, pure, modest, but incredibly authentic. Like a song sung in a white voice. Unhurried, not chatty, with little alcohol, totally old-fashioned.'

\section{Conclusion}

Winespeak in Polish is evolving quite fast, in fact much faster than the wine market. Blogs about wine expand upon specific language reflecting a dynamic and very subjective gustatory perception. In this type of discourse the metaphor's main function is to translate a personal sensory experience into more general ideas. We think that the relatively young culture of wine degustation in Poland is the reason that Polish winespeak abounds in metaphors which are creative and elaborated. Borrowed wine terms (round, long, rigid, etc.) seem to be hermetic and alien. Polish reviewers prefer to vividly expand those lexicalized metaphors and create story-like wine descriptions. Mixed metaphors, typical of winespeak, are also frequently represented in Polish discourse. Mixing several source frames to describe one concept-the taste of wine-results from the multi-dimensional taste sensation that develops in time. However, there are some constraints on metaphor mixing. It seems that antonym metaphors are mutually exclusive, e.g. wine cannot be described as simultaneously hot and cold, rigid and soft, aggressive and gentle. The proposed constraints will be tested in the future on various synesthetic metaphors (e.g. in perfumery discourse) as it is likely that the limitation also concerns other types of perception. Although wine discourse is rich in creative metaphors, sometimes even baffling, they are based on a very limited number of figurative schemata. The most prominent one is personification. Likewise, a very frequent schema is WINE IS A PHYSICAL OBJECT. Most metaphors exploiting that predication activate tactile experience (e.g. soft, smooth, harsh, rigid wine). It is owing to the metaphorization processes that the lexical field of gustatory experience in Polish winespeak is much bigger and diversified as compared to general Polish.

\section{Acknowledgments}

The article is funded by the National Science Centre in Poland under project no. 2014/15/B/ HS2/00182 titled: Microcorpus of Synaesthetic Metaphors. Towards a Formal Description and Efficient Methods of Analysis of Metaphors in Discourse.

\section{References}

Amoraritei, Loredana. 2002. La métaphore en œnologie. Metaphorik.de 3, 1-12.

Caballero, Rosario. 1996. Cutting across the senses: Imagery in winespeak and audiovisual promotion. In: Forceville, Charles and Eduardo Urios-Aparisi (eds.), Multimodal Metaphor, 73-94. Berlin/New York: Mouton de Gruyter.

Caballero, Rosario. 2007. Manner-of-motion verbs in wine description. Journal of Pragmatics 39(12), 2095-2114. 
Caballero, Rosario and Ernesto Suárez-Toste. 2010. A genre approach to imagery in winespeak: Issues and prospects. In: Low, Graham, Todd Zazie, Deignan Alice and Lynne Cameron (eds.), Researching and Applying Metaphor in the Real World, 265-287. Amsterdam/Philadelphia: John Benjamins Publishing Company.

Coulson, Seana. 2001. Semantic Leaps. Frame-Shifting and Conceptual Blending in Meaning. Cambridge: Cambridge University Press.

Creed, Allison. 2013. Wine and metaphor: cross-cultural [dis]harmony. In: Midgley, Warren, Trimmer Karen and Andy Davies (eds.), Metaphors for, in and of Education Research, 10-25. Newcastle upon Tyne: Cambridge Scholars Publishing.

Fillmore, Charles. 1982. Frame Semantics. In: Seoul International Conference on Linguistics, The Linguistics Society of Korea (eds.), Linguistics in the Morning Calm, 111-137. Seoul: Hanshin Publishing Co.

Gibbs, Raymond W. (ed.) 2016. Mixing Metaphor. Amsterdam/Philadelphia: John Benjamins Publishing Company.

Lakoff, George and Mark Johnson. 1980. Metaphors We Live By. Chicago: The University of Chicago Press.

Lehrer, Adrienne. 1975. Talking about Wine. Language 51(4), 901-923.

Lehrer, Adrienne. 2009 [1983]. Wine and conversation (Second edition). Oxford/New York: Oxford University Press.

Mitrenga, Barbara. 2009. Nazwy zmysłu smaku w języku polskim. LingVaria 4(2), 227-236.

Negro, Isabel. 2012. Wine discourse in the French language. RAEL: Revista Electrónica de Linguistica Aplicada 11, 1-12.

Paradis, Carita. 2010. Touchdowns in winespeak: ontologies and construals in use and meaningmaking. In: Rambaud, Margarita G. and Alfredo P. Luelmo (eds.), Proceedings from the 1st Conference on Linguistic Approaches to Food and Wine Descriptions, 37-55. Madrid: UNED.

Paradis, Carita and Mats Eeg-Olofsson. 2013. Describing sensory experience: The genre of wine reviews. Metaphor and Symbol 28(1), 22-40.

Paradis, Carita and Charlotte Hommerberg. 2016. We drink with our eyes first: The web of sensory perception, aesthetic experience and mixed imagery in wine reviews. In: Gibbs, Raymond W. (ed.), Mixing Metaphor, 179-201. Amsterdam/Philadelphia: John Benjamins Publishing Company. Skolik, Agnieszka. 2011. Smak w analizie sensorycznej. Poznań: Wydawnictwo UEP.

Suárez Toste, Ernesto. 2007. Metaphor inside the wine cellar: On the ubiquity of personification schemas in winespeak. Metaphorik.de 12(1), 53-64.

Țenescu, Alina. 2014. The organicist-animist metaphor in Italian wine media discourse. Social Sciences and Education Research Review 2, 62-72.

Zawisławska, Magdalena. 2015. Funkcja metafory w rekonstrukcji językowego obrazu świata na przykładzie metaforyki w języku winiarzy. Poradnik Językowy 1, 79-88. 


\section{Internet sources}

Naszkowska, Krystyna. 2017. Polacy piją coraz więcej wina - rośnie spożycie i produkcja. Jakie wina najchętniej kupujemy? Półwytrawne i tanie. http://wyborcza.pl/7,155287,21639178, polacy -pija-coraz-wiecej-wina-rosnie-spozycie-i-produkcja.html (15 April 2017) 